"Social media marketing, functional branding strategy and intentional branding"

\begin{tabular}{|c|c|}
\hline AUTHORS & Mohammad Fahmi Al-Zyoud (D https://orcid.org/0000-0003-2464-8162 \\
\hline ARTICLE INFO & $\begin{array}{l}\text { Mohammad Fahmi Al-Zyoud (2018). Social media marketing, functional branding } \\
\text { strategy and intentional branding. Problems and Perspectives in Management, } \\
\text { 16(3), 102-116. doi:10.21511/ppm.16(3).2018.09 }\end{array}$ \\
\hline DOI & http://dx.doi.org/10.21511/ppm.16(3).2018.09 \\
\hline RELEASED ON & Friday, 20 July 2018 \\
\hline RECEIVED ON & Sunday, 04 February 2018 \\
\hline ACCEPTED ON & Tuesday, 12 June 2018 \\
\hline \multirow{2}{*}{ LICENSE } & \\
\hline & $\begin{array}{l}\text { This work is licensed under a Creative Commons Attribution-NonCommercial } 4.0 \\
\text { International License }\end{array}$ \\
\hline JOURNAL & "Problems and Perspectives in Management" \\
\hline ISSN PRINT & $1727-7051$ \\
\hline ISSN ONLINE & $1810-5467$ \\
\hline PUBLISHER & LLC “Consulting Publishing Company "Business Perspectives" \\
\hline FOUNDER & LLC "Consulting Publishing Company "Business Perspectives” \\
\hline & $\begin{array}{l}\text { E: } \\
\text { E: }\end{array}$ \\
\hline NUMBER OF REFERENCES & NUMBER OF FIGURES \\
\hline 55 & 17 \\
\hline
\end{tabular}

C The author(s) 2023. This publication is an open access article. 


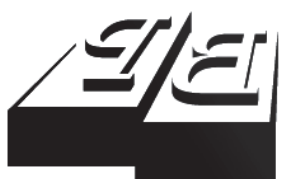

BUSINESS PERSPECTIVES

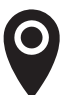

LLC "CPC "Business Perspectives" Hryhorii Skovoroda lane, 10, Sumy, 40022, Ukraine

www.businessperspectives.org

Received on: $4^{\text {th }}$ of February, 2018 Accepted on: $12^{\text {th }}$ of June, 2018

(C) Mohammad Fahmi Al-Zyoud, 2018

Mohammad Fahmi Al-Zyoud, Ph.D., Assistant Professor of Marketing, School of Business, Al-Ahliyya Amman University, Jordan.

\section{SOCIAL MEDIA MARKETING, FUNCTIONAL BRANDING STRATEGY AND INTENTIONAL BRANDING}

\begin{abstract}
It has been suggested that social media marketing may be inclined more towards functional branding than intentional branding. The present study empirically examined the relationship between social media marketing strategies, intentional branding and functional branding with a view to determining where social media marketing strategies are more strongly inclined towards intentional than functional branding. Quantitative data were collected from 133 participants from Jordan marketing departments using questionnaires and analyzed using SPSS. The results of the study confirmed the relationship between social media marketing strategies. However, results showed that social media marketing strategies are more strongly inclined towards intentional branding than functional branding suggesting that social media marketing strategies are oriented towards intentional branding. The study recommends examining the idea of intentional branding and its role in controlling the image of the brand among customers.
\end{abstract}

\section{Keywords \\ social media marketing, functional branding, intentional branding, e-marketing}

\section{JEL Classification M30, M31, M37}

\section{INTRODUCTION}

Utilizing the web, online networking, portable applications, and other advanced correspondence innovations has moved toward becoming part of billions of individuals' everyday lives. For example, the present rate of web use among American grown-ups is around $87 \%$ and is more like $100 \%$ for statistic gatherings, for example, school taught and higher-wage grown-ups. More youthful individuals - the up and coming era of mass customers - also have a very high usage (Kervyn, Fiske, \& Malone, 2012). Individuals likewise invest expanding energy on the web. For instance, in the UK, during the most recent decade, the number of hours spent online by grown-ups has dramatically increased, and now midpoints 20.5 hours per every week. Online networking has powered part of this development: worldwide, there are currently more than 2 billion individuals utilizing web-based social networking, and Facebook alone now has around 1 billion dynamic clients per each day (Bernritter, Verlegh, \& Smit, 2016).

\section{PROBLEM STATEMENT}

According to Kaplan and Haenlein (2010), social media can be defined as "a group of Internet-based applications that build on the ideological and technological foundations of Web 2.0 and allow the creation and exchange of user-generated content" (p. 61). O'Reilly (2005) defined social media as a broad concept that explains and presents the 
equipment and tools, which can evolve a content, which is generated by the users and able to be shared. According to Paquette (2013), social media provide many aspects that enable the organizations to share their brand and attain the needed attention to it. For example, social media websites can generate consumers' sentiment, motives, contents, attitudes and prospects through the virtual community that they build for the brand (Andrei \& Zait, 2014; Hashem, 2016).

\section{LITERATURE REVIEW}

\subsection{Technology and marketing}

The globalization of the world has been accompanied by technological advancements. These advances have brought changes in the marketplace and, in particular, in marketing communication industry and enabled companies to use digital marketing strategies to market and create value for their products. To this extent, several researchers agree that companies that make use of technology succeed in marketing their products and services (Ghorbani, Fakhimi, \& Ghorbani, 2013).

According to Chang (1996), for a company to create value for its product and succeed in marketing its products, it must ensure its marketing strategies are supported/backup with technology. Agreeing with Gingington and Zorob (1997), Foroudi et al. (2017) revealed that there is an interaction between marketing and technology, especially during product development. Similarly, Schneider (2003) argued that a stronger link must be created between marketing and research and development. Schneider (2003) believes that innovation may take vision and creativity. However, it is not sufficient for commercial success, as the vision and creativity of technologists cannot be clear enough to yield products/service that appeal to millions without investing in marketing.

Exploring the role and impact of technology in the marketing industry, Sooknanan and Crichlow (2014) also acknowledged that technology has a profound impact on e-marketing for North American businesses. According to Soonknanan and Crichlow (2014), regardless of the category, service or product, marketing is an important factor when it comes to the success of a business. Soonknanan and Crichlow (2014) further indicated that the proliferation of the Internet had revolutionized the marketing industry. It has altered the environmental dynamics and business environment in which marketers and businesses operate and changed the manner in which companies relate internally and externally with consumers as well as each other. Again, the proliferation of the Internet has also increased the available media from which marketers can use to market their products. Indeed, marketers can now choose from an assortment of Internet-based marketing alternatives (e-marketing); traditional media (radio and television), as well as non-mass media alternatively, including event marketing and direct mail. The availability of these marketing channels means consumers can be focused and creative when dealing with the increasingly demanding and sophisticated consumers.

Elsewhere, Applegate, Austin, and McFarlan (2002) acknowledged that new communication technologies, and, in particular, the Internet, have revolutionized the marketing communication landscape. They described the transformative effect of the Internet as seismic. Similarly, Zeng, Huang, and Dou (2009) acknowledged that interactive technology including smart cards, $\mathrm{m}$-commerce, enhanced computational speed, enhanced search services, GPS tracking and biometrics can be used to customize market strategy. Again, technological developments, including the search engines, peer-to-peer communication vehicles, advanced mobile interfaces and devices and social networks created online, have extended the ability of marketers to reach out to consumers through various touch points such as shopper marketing (Shankar et al., 2011). Through shopper marketing, consumers and business can interact and conduct business. During shopper marketing, marketers plan and execute marketing activities that influence shoppers when making purchases (Shankar et al., 2011). Shankar believes that shoppers can work together with shopper marketing to create clear messages, improve products, identify promoter and act as links to in-store activities. This way, they can demonstrate the value and importance of social media to retailers and marketers. 


\subsection{Social media websites as marketing tools}

Social media websites have evolved from simply offering a platform for people to link up with their friends and families in addition to the ability to reach and review their favorite products and services. Retailers and marketers alike utilize social media sites to provide consumers with the opportunity to shop and use it as a way to reach their consumers. Social networking sites are considered by shoppers as easy to use and useful. This makes them shop items through social media sites (Cha, 2009). According to Cha, it is easy for companies to reach their target customers through social media because of the availability of diverse consumers accessed via these sites. He indicates that this creates a platform for companies to market their products/brands/services to possible customers.

Töllinen and Karjaluoto (2011) and other (Liu et al., 2011; Dennis et al., 2009) hinted that social media websites are being used as marketing tools to increase marketing communications by increasing user-generated content (UGC) and customer interaction. According to Dennis et al. (2009), social media websites have helped marketers to embrace interactive communications by moving away from the traditional one-way communication to two-way communication with customers getting a chance to engage and participate in the communication loop. Supporting this view, Weinberg and Pehlivan (2011) hinted that marketers have recognized this new reality and are now considering social media as a state-of-the-art avenue for promoting products/services. This repetition of citations is really boring! Companies have recognized that social media can be used to elevate and increase multidimensional interaction and increase user-generated content and, therefore, dedicate part of their budget towards social media marketing. Approving this assertion, Aho Williamson (2011) confirmed that in 2011 in the U.S., businesses invested about USD 6 billion in social media marketing. Van Zyl (2009) and Riegner (2007) also agree that companies are using social media websites for marketing to generate content and increase customer engagedment. Social media are characterized by two factors: customer interaction and engagement and user-generated content. Van Zyl (2009) argues that these two characterize market- ing communication. Others (e.g., Muniz \& Schau, 2009; Riegner, 2007; Parent et al., 2011) clarify the importance of user-generated content and customer interaction and the creation of content in marketing by indicating that user-generated content help to increase customers' value experience, and that customer-based content creation and active interaction help a business enterprise to build a strong and long-term competitive advantage.

According to Muniz and Schau (2009), fluent and interactive customer service encourages purchasers to take part in service and product creation. Supporting their view, Hanna et al. (2011) argued that social media websites allow customers to take active roles in marketing of the product. Weinberg and Pehlivan (2011) also believe that social media empowers consumers and allows to create the relationship between customers and organizations.

\subsection{Branding and service design}

Branding is the way a company or business enterprise is personalized in the consumers' minds. Building and managing a brand, its name, its reputation and its identity is critical to the success of any company. How, where and when a company connects with its customers is determined by its branding and by how much consumers of its products/services relate to its brand. In today's competitive market, the branding is the company's strongest differentiator.

\subsection{Functional branding}

In service design, functional branding involves creating or improving services with the aim of enhancing user experience. It involves creating services by applying service design with a view to deliver a branded experience to the user. Functional branding enables a company to differentiate itself by positively reinforcing the value of its brand through design. Every time the user interacts with the company's brand, the company seizes that opportunity to influence their perceptions. Functional branding is aimed at turning every interaction into a branded experience by ensuring that users receive a positive experience and the interaction conveys the company's brand values. These user experiences appeal to consumers emotionally and have excellent usability and function- 
ality. Functional branding depends on the comprehensive and overall branded experience. As such, it can increase brand equity and brand loyalty (Töllinen \& Karjaluoto, 2011).

Customers typically buy functional brands to satisfy their functional need. In the consumers' mind, functional brands are often tied to specific product categories. These brands typically share the association of the user with other brands belonging to the same category. These brands should differentiate from brands of the competitor by stressing either better economy or better performance. For example, BMW's produces products that compete on performance. It maintains category leadership in automobile by spending heavily on research and design $(\mathrm{R} \& \mathrm{D})$ to produce automobiles that have a greater cutting edge design, are faster and more luxurious than competitors (Lawford, 2009). For this reason, cars produced by BMW are known for their elegant and sophisticated styling, as well as for high performance. Accordingly, new car models launched by BMW are positioned based on its marketing and elegant and sophisticated qualities.

In contrast, Kia automobile company is known for producing car models that compete based on their perceived economic value rather than on performance. Although Kia spends part of its money on research and development, the focus is on identifying ways to minimize costs through simpler design, increased manufacturing efficiency and more modest features. The ability of Kia to produce relatively cheaper, but attractive and high-quality products, makes it to compete others. This shows that a company that establishes and manages a functional brand focuses on a marketing mix: either on the price and place (for superior economy) or product/service itself (for superior performance). Messaging and advertising should not only support the link between the category and the brand, but also emphasize what should make a brand/product superior, either in price and value or functionality and features. Examples of functional brands include dish soap, cell phones and automobiles.

\subsection{Intentional branding}

According to Rick (2008), all businesses need a brand. Regardless of the purpose, industry or size, an engaging and attractive brand is abso- lutely essential. However, it is not just any brand but an intentional brand. This is a type of brand, which is built willfully, with purpose and planning. According to Pietro and Pantano (2012), a brand is created out of perception and this perception is, to a prospective consumer, a reality. Pietro and Pantano (2012) further indicated that a brand built without intention is subject to open interpretation by customers. According to Shu-Chuan (2011), this explains why it is important for a company to be in the driver's seat while building a brand. This means conveying the right image, as well as delivering the right message that serves its target customers and, consequently, its business and itself. An intentional brand is authentic, sincere, confident, valuable, credible, accountable, and result-driven. Intentional branding includes the branding decisions that are made when developing the look and feel of a company in order to make it create the best identity that reflects its target market. According to Chi (2011), a brand is a like a company logo; its font choice, paper weight, lighting, color selection, photo style, the feeling brand evoke emotions in the customer. International branding means the company being in control of message it sends to its audience. A clear and not confusing message means the company is doing its job correctly. Intentional branding reflects image branding. It is aimed at creating specific perceptions in the minds of the user. Companies that embrace intentional branding tend to differentiate themselves, because customers perceive them as proving unique image or association. These companies either establish image based on luxury and high style or on product features. They make use of advertising to create associations that do not depend on features. Managing intentional branding is a function of establishing an emotional link with the consumer, as intentional branding largely depends on the ability of the company to tap into the desires of the consumer to be admired or belong to a certain group. For this reason, advertising plays an important role in marketing of these brands, as well as publicity and sponsorships.

Cox (2010) identified nine keys to building an intentional brand: authenticity, confidence, sincerity, accountability, credibility, experience, value, results, referrals. Cox (2010) further suggested that intentional branding efforts should work to differ- 
entiate a company in its market; where if it tends towards the disruptive side, the intentional branding efforts should follow the lead of the product.

\subsection{Brand - positioning}

Brand positioning is an important concept in marketing that was first conceptualized by Ries and Trout as part of value proposition and brand identity that describes how a company can compete effectively within the target market. It can also refer to the message that a company imprints in the customers' mind and the prospects regarding its service or product and how it differs from what competitors are offering. Companies often develop a brand position with a view to define the specific place/position to be occupied by the brand in the consumers' mind.

Four elements define brand positioning: target market; frame, category, competitive set or reference; differentiation; supporting points or proof. According to Maarit Jalkala and Keränen (2014), it is impossible to complete a positioning statement without defining a target market. Companies can only develop a strong positioning of their brands by understanding the target market. A brand may appeal to many target markets. However, it each market may require a different position.

For a company to determine the category, competitive set or frame of reference it will use in defining its brand positioning, it must understand the relevant options that consumers (target market) see as available. The frame of reference defines the company's marketplace that positions its brand and facilitates its differentiation and definition. Differentiation or unique selling proposition (USP), value proposition or brand promise is typically what makes a brand unique or different from others in its frame of reference. Singh Kalafatis and Ledden (2014) noted that it gives consumers a reason to choose to buy the brand, as strong differentiation clearly separates a company's brand from competitors. It is a decision guide that serves to increase the behavior standard and operational efficiency for the company. Brand positioning is defined by supporting points or proof of why the target market should believe the company. Supporting points are attributes of a brand that supports the claim that it is the best brand in the market. Brand positioning is an important element of marketing and brand strategy. Communicating brand position externally to the market and internally to the organization helps to make company's marketing program more focused, efficient and effective.

\subsection{Social media and branding/ positioning}

Social media can serve as channels for marketers to conduct marketing activities, including customer service, customer relationship management, sales promotion delivery channel, lead generation, paid advertising channels, as well as branding (Schmitt, 2012). As noted in eMarketer (2013), marketers identify social media platforms as a branding channel that companies can use in order to create brand attention and awareness, promote customer loyalty and engagement, increase brand popularity, encourage word-of-mouth connections with consumers regarding a brand and to drive the attention towards a specific brand. These branded social activities can involve a range of activities, such as dialogue, engagement experiences, socially published branded content, and social participation of brand persona (Hutton \& Fosdick, 2011; Falls, 2010).

Stelzner (2013) observed that marketers may use social media to expose their target customers to a brand message, to improve search rankings, to increase traffic to their brand, and increase customer loyalty towards their brand. Doorn et al. (2010) also believe that companies may use social media to increase customer engagement. According to Doorn et al. (2010), customer engagement extends beyond purchase. It is behavior-based and focuses on a brand. According to Doorn et al. (2010), purchasers may engage with the brand along the following characteristics: scope (geographic and temporal), valence (value), form (type of resources used), customer goals for engagement and impact.

Merchant (2006) argues that social media platforms offer a form of identified performance and that brands are part of it. This way, they allow consumers to share branded content and their own opinion with their network. Falls (2010) agrees with Merchant and adds that in the social media, consumers' response is measured based on wheth- 
er they bookmark, refers to others' blogs, links, connect, click, subscribe, connect friends, submit an idea or an inquiry or purchase a brand.

\subsection{Is social media marketing functional or intentional?}

Based on the literature, social media marketing tends more towards functional branding than intentional branding, as it utilizes brand posts and brand pages to create services with the aim of enhancing user experience. As noted by Lipsman et al. (2012) one of the most meaningful, organic and influential ways via which brands use social media marketing is brand posts and brand pages. As noted by Tafesse (2015), brand pages represent an interactive and dedicated platform, which is created by brands or companies on the social media websites aimed at increasing brand communication and customer interaction. Brand pages enable brands to cultivate personalized, regular and direct interaction with them and create an active online community (Kim, Spiller, \& Hettche, 2015; Ashley \& Tuten, 2015).

Brand pages are made up of a community of brand fans, customers, consumers, influencers, employers' fans, and others who subscribe to the update of a brand voluntarily (Zaglia, 2013; Pereira et al., 2014).

Customers who follow or like brand pages often expose themselves to other consumers' comments, fan posts and reactions and to regular communications of a brand. Brand pages are associated with interactivity tools, including comment, like, private, share, public messages, and leaving private messages on the pages. These tools empower users to express their feelings, voice their opinions and share personal experiences about a brand. To real-time user, this interactivity creates an environment for co-creating a rich brand experience (Zaglia, 2013; Tafesse, 2016).

Brand posts represent a frequent, unpaid and concise updates sent out to fans and customers on a daily basis and which are authored by brands. Brands directly send updates to fans and customers in their newsfeed or whenever they visit brand pages they are subscribed to (Ashley \& Tuten, 2015; Lipsman et al., 2012). Brand posts are sent out to customers as recurrent updates. They ensure brands maintain their presence on the social media platforms. They serve to strengthen the relationship between the brands with customers by offering the ongoing conversations' theme. They support multiple types of media, including photo website links, text, photo) and communicate brand experiences and meaning (Gensler et al., 2013; Tafesse, 2016). Brand posts can be utilized in building brand awareness, delivering emotional stories, introducing new products, stimulating purchases, and educating customers (Taecharungroj, 2016; Kim et al., 2015). Brand posts have automatic response options, including share, comment and like. They play an important role in connecting brands with fans and customer (Taecharungroj, 2016).

\section{METHODOLOGY}

This section described the methodology followed to conduct the present study. It details the study approach, the tool used to collect data, the study population, sample size and sampling technique used.

\subsection{Study approach}

This study assumed the quantitative approach to the research, which involved collecting quantitative data that could be numerically represented and manipulated to help to describe and explain the possible relationship between social media marketing and functional branding than intentional branding, as suggested by Sukamolson (2007, p. 2). In line with the view by Zalaghi and Khazaei (2016), and Borrego, Doulas, and Amelink (2009), this study was deductive in that it was narrow in its approach and aimed at confirming or testing the hypotheses.

\subsection{Data collection tool}

Data were collected using the structural questionnaire. The questionnaire contained two sections: section A and section B. Section A contained questions on demographics of participants. Section B contained questions on study variables. The questionnaire contained closed-ended questions with answers that required respondents to rate based 
on the Likert scale ranging from 1 to 5 with 1 denoting strongly disagree, 2 - disagree, 3 - neutral, 4 - agree and 5 - strongly agree. The questions focused on three constructs under investigation: functional branding, intentional branding and social media marketing. Functional branding was operationalized into usability and customer interactions and questions were designed to measure these two variables. Questions were tailored towards determining whether, from the respondents' perspective, social media marketing tends more towards functional branding than intentional branding, as suggested in the literature. The questionnaires were distributed through drop and pick to study participants.

\subsection{Population and sample}

The study population consisted of managers, leaders and heads of departments of organizations within the Jordanian iron and metal industry. A convenient sampling was used in this study. The sample consisted of 150 participants including leaders, managers, heads of departments and employees from the Jordanian marketing department. However, out of the 150 questionnaires send to the participants, 133 responded to and sent back the questionnaire. This converted into response rate of $88.6 \%$, which is reasonably good. This sample size was also large enough to justify the conclusion reached and the generalization of the study findings to the general marketing field.

\subsection{Data analysis}

The quantitative data collected using questionnaires were analyzed using Statistical Package for Social Sciences (SPSS) version 17. Accordingly, correlation analysis and descriptive analysis were undertaken. Reliability test was also done using SPSS to ascertain the reliability of the questionnaire to measure the study variables. Data were presented in the tables.

\subsection{Questions and hypotheses}

The current study seeks to examine whether social media marketing strategies are inclined towards intentional or functional branding. From that point, it seeks to answer the following questions:

\subsubsection{Questions of the study}

1. What is functional branding and how it appears in social media marketing?

2. What is intentional branding and how it appears in social media marketing?

3. What is the orientation of social media marketing between the functional strategy and the intentional strategy?

4. Which strategy may attract a customer to convert from a browser into a paying customer?

\subsubsection{Main hypotheses}

H1: Functional branding positively and significantly influences social media-based marketing strategies.

H2: Intentional branding positively and significantly influences social media-based marketing strategies.

H3: Social media marketing strategies are more strongly inclined towards intentional branding than functional branding.

\subsubsection{Sub-hypotheses}

$H 1^{a}$ : Usability positively and significantly influences social media-based marketing strategies.

$H 1^{b}$ : Customer interaction positively and significantly influences social media-based marketing strategies.

$H 2^{c}$ : Intention positively and significantly influences on social media-based marketing strategies.

$H 2^{d}$ : Ability positively and significantly influences on social media-based marketing strategies.

$H 3^{e}$ : Social media marketing strategies are more strongly inclined towards ability and intention than usability and customer interaction. 


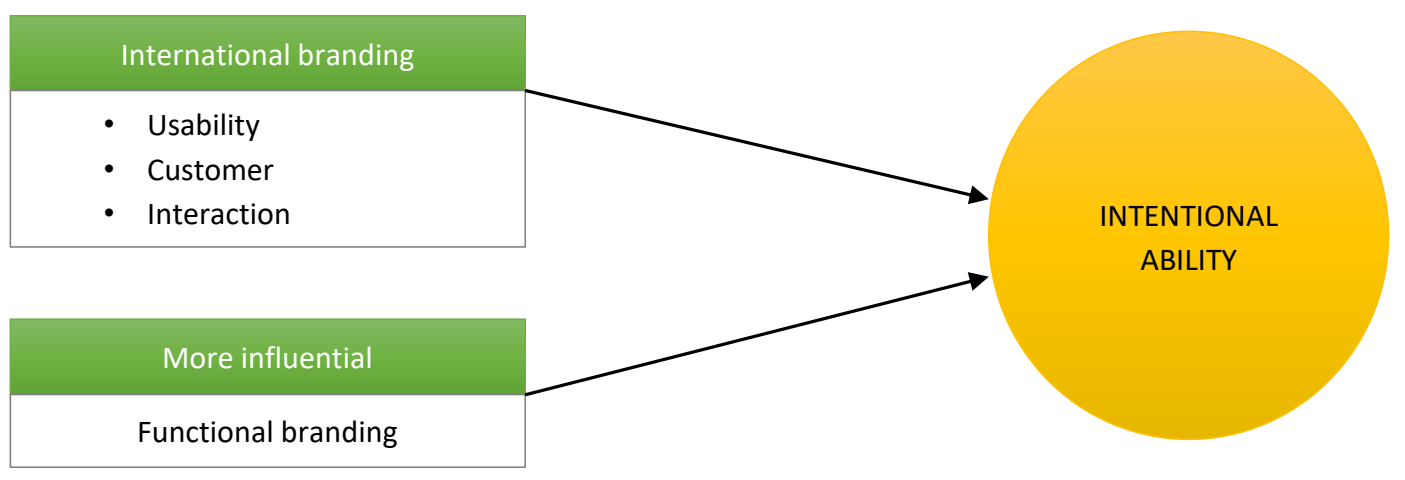

Figure 1. Conceptual framework relating functional branding and intentional branding variables with social media marketing strategies

\section{RESULTS: ANALYSIS}

\subsection{Age}

Based on the respondents' age (one of the demographic variables), $60.9 \%$ of respondents were aged 33-40 (Table 1). This appeared to be logical given that this age range is more apparent within organizations for individuals to hold such a position in marketing and advertising that are based on technology and Internet. Individuals at that age are exposed to technology and able to use in their daily work activities.

Table 1. Characteristics of respondents based on their age

\begin{tabular}{|c|c|c|c|c|c|}
\hline \multicolumn{2}{|c|}{ Age } & Frequency & Percent & Valid & Cumulative \\
\hline \multirow{4}{*}{ Valid } & $25-32$ & 26 & 19.5 & 19.5 & 19.5 \\
\hline & $33-40$ & 81 & 60.9 & 60.9 & 80.5 \\
\hline & +41 & 26 & 19.5 & 19.5 & 100.0 \\
\hline & Total & 133 & 100.0 & 100.0 & \\
\hline
\end{tabular}

\subsection{Education}

As shown in Table 2, majority (46.6\%) of the respondents in the marketing department are holders of MA degree or equivalent qualifications with the frequency 62. There are also more $\mathrm{PhD}$ holders in the marketing department than Bachelor's holders, as there were more respondents with $\mathrm{PhD}$ degrees (38.3\%) than those with Bachelor's degrees (15.0\%) (Table 2). Again as can be inferred from Table 2, most of respondents who held higher positions marketing and advertising in an organization held a post graduate degree, which indicates high competence and high knowledge of the field and deep interest.
Table 2. Frequency and percentage of sample characteristics according to education

\begin{tabular}{|c|c|c|c|c|c|}
\hline \multicolumn{2}{|c|}{ Education } & \multirow{2}{*}{$\frac{\text { Frequency }}{20}$} & \multirow{2}{*}{$\frac{\text { Percent }}{15.0}$} & \multirow{2}{*}{$\begin{array}{c}\begin{array}{c}\text { Valid } \\
\text { percent }\end{array} \\
15.0\end{array}$} & \multirow{2}{*}{$\begin{array}{c}\begin{array}{c}\text { Cumulative } \\
\text { percent }\end{array} \\
15.0\end{array}$} \\
\hline \multirow{4}{*}{ Valid } & BA & & & & \\
\hline & $\mathrm{MA}$ & 62 & 46.6 & 46.6 & 61.7 \\
\hline & $\mathrm{PhD}$ & 51 & 38.3 & 38.3 & 100.0 \\
\hline & Total & 133 & 100.0 & 100.0 & \\
\hline
\end{tabular}

\subsection{Experience}

Table 3. Frequency and percentage of sample characteristics according to experience

\begin{tabular}{|c|c|c|c|c|c|}
\hline \multicolumn{2}{|c|}{ Experience } & \multirow{2}{*}{$\begin{array}{c}\text { Frequency } \\
20\end{array}$} & \multirow{2}{*}{$\frac{\text { Percent }}{15.0}$} & \multirow{2}{*}{\begin{tabular}{|c|}
$\begin{array}{c}\text { Valid } \\
\text { percent }\end{array}$ \\
15.0
\end{tabular}} & \multirow{2}{*}{\begin{tabular}{|c|}
$\begin{array}{c}\text { Cumulative } \\
\text { percent }\end{array}$ \\
15.0
\end{tabular}} \\
\hline \multirow{5}{*}{ Valid } & $5-10$ & & & & \\
\hline & $11-16$ & 87 & 65.4 & 65.4 & 80.5 \\
\hline & $17-22$ & 14 & 10.5 & 10.5 & 91.0 \\
\hline & $23+$ & 12 & 9.0 & 9.0 & 100.0 \\
\hline & Total & 133 & 100.0 & 100.0 & \\
\hline
\end{tabular}

As shown in Table $3,65.4 \%$ of the respondents had experience ranging 11-16 years with a frequency of 87 individuals. It can also be seen that $15 \%$ of the respondents had experience ranging 5-10 years. This indicated that organizations from which the sample of the study was drawn used technology in its marketing and advertising activities and increased its interest during the last decade on using social media in marketing.

\subsection{Descriptive analysis}

As shown in Table 4, respondents were largely in agreement with most of the suggested responses to the questions. As the table showed, the mean of paragraphs scoring higher than 3.00 was a good indicator, as it suggests that participants 
either agree or strongly agree to the statements that were detailed in the questionnaire with regard to social media marketing and functional branding. As can be seen from the table, the mean of the responses from respondents in relation to social media was above 3 (i.e., 3.744 for the first question, 3.7770 for question 2, 3.59.40 for question 3 and 3.7.068 for question 5. This confirms that participants agree or strongly agree that marketing through social media can create and exchange user generated content; consumers' sentiment toward marketing can appear through using social media; social media has the ability to highlight the consumer's acceptance of new technology; and social media marketing can create a virtual community for the brand. Similarly, with the mean value of responses scoring above 3 for the functional branding and intentional branding variables (usability and customer orientation, ability and intentional variables) (Table 4), respondents agree that functional branding and intentional branding play an important role in social media marketing. These results indicate that individuals are positive about the involvement of social media within the marketing field and how it can help in developing the marketing process leading to more customers and better branding.

Table 4. Descriptive statistics

\begin{tabular}{|c|c|c|c|c|c|}
\hline Question & $\mathbf{N}$ & Minimum & Maximum & Mean & $\begin{array}{l}\text { Std. } \\
\text { deviation }\end{array}$ \\
\hline \multicolumn{6}{|c|}{$\begin{array}{l}\text { Social media marketing } \\
\end{array}$} \\
\hline $\begin{array}{l}\text { Marketing through social media can create and exchange user } \\
\text { generated content }\end{array}$ & 133 & 1.00 & 5.00 & 3.7444 & 1.04195 \\
\hline $\begin{array}{l}\text { Consumers' sentiment toward marketing can appear through } \\
\text { using social media }\end{array}$ & 133 & 2.00 & 5.00 & 3.7970 & .97514 \\
\hline $\begin{array}{l}\text { Social media has the ability to highlight the consumer's } \\
\text { acceptance of new technology }\end{array}$ & 133 & 2.00 & 5.00 & 3.5940 & 1.14175 \\
\hline $\begin{array}{l}\text { Social media marketing can create a virtual community for the } \\
\text { brand }\end{array}$ & 133 & 2.00 & 5.00 & 3.7068 & 1.05012 \\
\hline \multicolumn{6}{|c|}{$\begin{array}{ll} & \text { Intentional branding } \\
\end{array}$} \\
\hline \multicolumn{6}{|l|}{ Intentions } \\
\hline Intentions give confidence in the brand & 133 & 2.00 & 5.00 & 3.8195 & .93610 \\
\hline Intentions give more authenticity to the brand & 133 & 2.00 & 5.00 & 3.8722 & .98791 \\
\hline Intentions present the brand more sincere and genuine & 133 & 2.00 & 5.00 & 3.9248 & .88441 \\
\hline Intentions build assurance within the customer & 133 & 2.00 & 5.00 & 3.9398 & .94355 \\
\hline Intentions increase the accountability of the brand & 133 & 2.00 & 5.00 & 3.9624 & .98785 \\
\hline \multicolumn{6}{|l|}{ Ability } \\
\hline $\begin{array}{l}\text { Intentional branding gives more ability to the brand to sound } \\
\text { more credible }\end{array}$ & 133 & 2.00 & 5.00 & 4.1579 & .86025 \\
\hline $\begin{array}{l}\text { Intentional branding increases the ability of the brand to deepen } \\
\text { the customers' experience }\end{array}$ & 133 & 2.00 & 5.00 & 3.9699 & .91237 \\
\hline $\begin{array}{l}\text { Intentional branding gives more ability to the brand to show its } \\
\text { perceptions }\end{array}$ & 133 & 2.00 & 5.00 & 3.9850 & .92920 \\
\hline The ability of the brand gives it more social perception & 133 & 3.00 & 5.00 & 3.8872 & .84076 \\
\hline Ability gives more value to the brand & 133 & 2.00 & 5.00 & 4.0150 & .89599 \\
\hline \multicolumn{6}{|c|}{ Functional branding } \\
\hline \multicolumn{6}{|l|}{ Usability } \\
\hline The function of the brand supports its usability & 133 & 2.00 & 5.00 & 3.8120 & 95466 \\
\hline $\begin{array}{l}\text { Functional branding deviates the intention in the customer into } \\
\text { reality through its functions }\end{array}$ & 133 & 2.00 & 5.00 & 3.8120 & .92237 \\
\hline $\begin{array}{l}\text { Functional branding doesn't leave the brand open for } \\
\text { interpretations }\end{array}$ & 133 & 2.00 & 5.00 & 3.6466 & 1.00902 \\
\hline $\begin{array}{l}\text { Intentional branding gives more details to the characteristics of } \\
\text { the brand }\end{array}$ & 133 & 2.00 & 5.00 & 3.5564 & 1.13760 \\
\hline $\begin{array}{l}\text { Through functional branding, the usability and handling of the } \\
\text { product becomes easier }\end{array}$ & 133 & 1.00 & 5.00 & 3.3684 & 1.38976 \\
\hline \multicolumn{6}{|l|}{ Customer interaction } \\
\hline Customer interaction increases the brand equity & 133 & 2.00 & 5.00 & 3.5263 & 1.07717 \\
\hline Customer interaction increases the customers' functional needs & 133 & 2.00 & 5.00 & 3.5865 & 1.04539 \\
\hline Interaction gives more perspective to the brand & 133 & 2.00 & 5.00 & 3.4511 & 1.06931 \\
\hline $\begin{array}{l}\text { Social media marketing gives a slight sense of customer } \\
\text { interaction }\end{array}$ & 133 & 2.00 & 5.00 & 3.6165 & .98259 \\
\hline
\end{tabular}




\subsection{Reliability test}

Depending on the reliability using Cronbachs' alpha, the test indicated a total value of 0.971 , also, Cronbachs' alpha for every variable was greater than 0.60 , this can be regarded as a logical value referring to the questionnaire consistency.

\subsection{Hypotheses testing}

The following section presents the testing of the hypotheses based on the variables of the model in accordance to their influence.

H1: Functional branding positively and significantly influences social media-based marketing strategies.

As can be inferred from Table 5, functional branding and social media marketing are strongly and positively correlated $(R=0.476)$. It can also be confirmed from Table $6(F=19.074)$ that the relationship between social media marketing and functional branding is significant suggesting that functional branding positively and significantly influences social media-based marketing strategies.

Table 5. Correlation analysis between social media marketing strategies and functional branding

\begin{tabular}{c|c|c|c|c}
\hline Model & $\mathbf{R}$ & R square & $\begin{array}{c}\text { Adjusted R } \\
\text { square }\end{array}$ & $\begin{array}{c}\text { Std. error of } \\
\text { the estimate }\end{array}$ \\
\hline 1 & $.476 \mathrm{a}$ & .227 & .215 & .85738 \\
\hline
\end{tabular}

Table 6. Regression analysis between social media marketing strategies and functional branding

\begin{tabular}{|c|c|c|c|c|c|c|}
\hline & \multicolumn{6}{|c|}{ ANOVAa } \\
\hline & Model & $\begin{array}{l}\text { Sum of } \\
\text { squares }\end{array}$ & df & $\begin{array}{l}\text { Mean } \\
\text { square }\end{array}$ & $\mathbf{F}$ & Sig. \\
\hline \multirow{3}{*}{1} & Regression & 28.042 & 2 & 14.021 & 19.074 & $.000 b$ \\
\hline & Residual & 95.562 & 130 & .735 & - & - \\
\hline & Total & 123.604 & 132 & - & - & - \\
\hline
\end{tabular}

Linear regression was used to test this hypothesis; it was noticeable that $R(0.451)$ was the correlation of the usability and social media-based marketing strategies. In addition to that, $F$ value of 33.417 was significant at 0.05 level. Based on that, there is a statistically significant influence of usability on social media marketing (Tables 7 and 8).
H1a: Usability positively and significantly influences social media-based marketing strategies.

Table 7. Correlation analysis between social media marketing strategies and functional branding: usability

\begin{tabular}{c|c|c|c|c}
\hline \multicolumn{5}{|c}{ Model summary } \\
\hline Model & $\mathbf{R}$ & R square & $\begin{array}{c}\text { Adjusted R R } \\
\text { square }\end{array}$ & $\begin{array}{c}\text { Std. error } \\
\text { of the } \\
\text { estimate }\end{array}$ \\
\hline 1 & $.451 \mathrm{a}$ & .203 & .197 & .86705 \\
\hline
\end{tabular}

Table 8. Regression analysis between social media marketing strategies and functional branding: usability

\begin{tabular}{|c|c|c|c|c|c|c|}
\hline & \multicolumn{6}{|c|}{ ANOVAa } \\
\hline & Model & $\begin{array}{l}\text { Sum of } \\
\text { squares }\end{array}$ & df & $\begin{array}{l}\text { Mean } \\
\text { square }\end{array}$ & $\mathbf{F}$ & Sig. \\
\hline \multirow{3}{*}{1} & Regression & 25.122 & 1 & 25.122 & 33.417 & $.000 \mathrm{~b}$ \\
\hline & Residual & 98.483 & 131 & .752 & - & - \\
\hline & Total & 123.604 & 132 & - & - & - \\
\hline
\end{tabular}

Linear regression was used to test this hypothesis; it was found that $R(0.472)$ was the correlation of customer interaction and the social media-based marketing strategies and $F$ value of 37.489 is significant at 0.05 level. So, there is a statistically significant influence Customer Interaction and social media marketing (Tables 9 and 10).

$H 1^{e}$ : Customer interaction positively and significantly influences social media-based marketing strategies.

Table 9. Correlation analysis between social media marketing strategies and functional branding: interaction

\begin{tabular}{c|c|c|c|c}
\hline \multicolumn{5}{c}{ Model summary } \\
\hline Model & $\mathbf{R}$ & R square & $\begin{array}{c}\text { Adjusted R } \\
\text { square }\end{array}$ & $\begin{array}{c}\text { Std. error of } \\
\text { the estimate }\end{array}$ \\
\hline 1 & $.472 \mathrm{a}$ & .222 & .217 & .85651 \\
\hline
\end{tabular}

Table 10. Regression analysis between social media marketing strategies and functional branding: interaction

\begin{tabular}{|c|c|c|c|c|c|c|}
\hline \multicolumn{7}{|c|}{ ANOVAa } \\
\hline & Model & $\begin{array}{l}\text { Sum of } \\
\text { squares }\end{array}$ & df & $\begin{array}{l}\text { Mean } \\
\text { square }\end{array}$ & $\mathbf{F}$ & Sig. \\
\hline \multirow{3}{*}{1} & Regression & 27.502 & 1 & 27.502 & 37.489 & $.000 \mathrm{~b}$ \\
\hline & Residual & 96.102 & 131 & .734 & - & - \\
\hline & Total & 123.604 & 132 & - & - & - \\
\hline
\end{tabular}


H2: Intentional branding has a positive and significant influence on social media-based marketing strategies.

As can be seen from Tables 11 and 12, the analysis shows that the intentional branding and social media-based marketing strategies are strongly correlated $(R=0.918)$ and that the relationship is statistically significant $(F=346.096)$ at $p=0.05$ significance level, which means that intentional branding has a significant influence on social media-based marketing strategies.

Table 11. Model summary

\begin{tabular}{c|c|c|c|c}
\hline Model & $\mathbf{R}$ & $\begin{array}{c}R \\
\text { square }\end{array}$ & $\begin{array}{c}\text { Adjusted } R \\
\text { square }\end{array}$ & $\begin{array}{c}\text { Std. error of } \\
\text { the estimate }\end{array}$ \\
\hline 1 & $.918^{\mathrm{a}}$ & .842 & .839 & .38773 \\
\hline
\end{tabular}

Table 12. ANOVA

\begin{tabular}{c|c|c|c|c|c|c}
\hline Model & $\begin{array}{c}\text { Sum of } \\
\text { squares }\end{array}$ & df & $\begin{array}{c}\text { Mean } \\
\text { square }\end{array}$ & F & Sig. \\
\hline \multirow{2}{*}{1 Regression } & 104.061 & 2 & 52.030 & 346.096 & $.000 b$ \\
\cline { 2 - 7 } & Residual & 19.544 & 130 & .150 & - & - \\
\cline { 2 - 6 } & Total & 123.604 & 132 & - & - & - \\
\hline
\end{tabular}

$\mathrm{H}^{a}$ : Ability has a positive and significant influence on social media-based marketing strategies.

As can be inferred from Tables 13 and 14, ability and social media marketing strategies are strongly and positively correlated $(R=0.488)$ and that the relationship is significant at $p=0.05$ significance level at $F=40.942$. Thus, there is a statistically significant influence of ability on social media marketing.

Table 13. Model summary

\begin{tabular}{c|c|c|c|c}
\hline Model & $\boldsymbol{R}$ & $\begin{array}{c}\boldsymbol{R} \\
\text { square }\end{array}$ & $\begin{array}{c}\text { Adjusted } \boldsymbol{R} \\
\text { square }\end{array}$ & $\begin{array}{c}\text { Std. error of } \\
\text { the estimate }\end{array}$ \\
\hline 1 & $.488^{\mathrm{a}}$ & .238 & .232 & .84786 \\
\hline
\end{tabular}

Table 14. ANOVA ${ }^{a}$

\begin{tabular}{|c|c|c|c|c|c|c|}
\hline & Model & $\begin{array}{l}\text { Sum of } \\
\text { squares }\end{array}$ & df & $\begin{array}{l}\text { Mean } \\
\text { square }\end{array}$ & $\mathbf{F}$ & Sig. \\
\hline & Regression & 29.432 & 1 & 29.432 & 40.942 & $.000 \mathrm{~b}$ \\
\hline \multirow[t]{2}{*}{1} & Residual & 94.172 & 131 & .719 & - & - \\
\hline & Total & 123.604 & 132 & - & - & - \\
\hline
\end{tabular}

$H 2^{b}$ : Intention has a positive and significant influence on social media-based marketing strategies.
As can be observed from Tables 15 and 16, intention and social media-based marketing strategies are correlated $(R=0.908)$ and the relationship is statistically significant at $p=0.05$ significance level at $F=613.369$. Thus, there is a statistically significant influence of intention on social media marketing.

Table 15. Model summary

\begin{tabular}{c|c|c|c|c}
\hline Model & $\boldsymbol{R}$ & $\boldsymbol{R}$ square & $\begin{array}{c}\text { Adjusted } \\
\text { R square }\end{array}$ & $\begin{array}{c}\text { Std. error of } \\
\text { the estimate }\end{array}$ \\
\hline 1 & $.908 \mathrm{a}$ & .824 & .823 & .40750 \\
\hline
\end{tabular}

Table 16. ANOVA

\begin{tabular}{|c|c|c|c|c|c|c|}
\hline & Model & $\begin{array}{c}\text { Sum of } \\
\text { squares }\end{array}$ & df & $\begin{array}{c}\text { Mean } \\
\text { square }\end{array}$ & $F$ & Sig. \\
\hline \multirow{3}{*}{1} & Regression & 101.851 & 1 & 101.851 & 613.369 & $.000 \mathrm{~b}$ \\
\hline & Residual & 21.753 & 131 & .166 & - & - \\
\hline & Total & 123.604 & 132 & - & - & - \\
\hline
\end{tabular}

H3: Social media marketing strategies are more strongly inclined towards ability and intention than usability and customer interaction.

As can be seen from Table 17, among participants, there is a strong inclination towards intention and ability (which are variables of intentional branding) than usability and interaction (variable of functional branding) with means of intention and ability being higher than those of interaction and usability suggesting that participants believe that social media marketing strategies may be more inclined towards intentional branding than functional branding.

Table 17. Descriptive statistics

\begin{tabular}{|c|c|c|c|c|c|}
\hline Dimension & $\mathbf{N}$ & Minimum & Maximum & Mean & $\begin{array}{c}\text { Std. } \\
\text { deviation }\end{array}$ \\
\hline Intention & 133 & 2.40 & 5.00 & 3.7323 & .93611 \\
\hline Ability & 133 & 2.60 & 5.00 & 3.9714 & .85179 \\
\hline Usability & 133 & 2.80 & 5.00 & 3.3338 & .81416 \\
\hline Interaction & 133 & 2.25 & 5.00 & 3.5959 & .95828 \\
\hline $\begin{array}{l}\text { Dep } \\
\text { (Dependency) }\end{array}$ & 133 & 2.25 & 5.00 & 3.5451 & .96768 \\
\hline
\end{tabular}

\section{DISCUSSION}

This study sought to determine empirically whether social media marketing is more oriented towards intentional branding rather than functional branding, as suggested in the literature. Results 
suggested that though both functional and intentional branding influence on social media marketing strategies, social media marketing strategies tend to be more inclined towards intentional branding than functional branding. This is contrary to what has been suggested in the extant literature that social media marketing may be more oriented towards functional branding rather than intentional branding.

This finding suggests that through social media, the organization would be able to build a community for its brand as a sort of what is called consumer-brand relationship (CBR). The idea of this type of community is the fact that it is built on social media so it is more of an online community and there is no way to be offline. This is called "Online Consumer Community (OCC)" (Andrei \& Zait, 2014; Fournier \& Alvarez, 2011).

The OCC is seen as a somewhat new concept, but the way it is used and operated still differs across studies, (Bhat \& Reddy, 1998). This is evidenced by many jargons that appeared through the previous studies which highlighted the role of social media in marketing like online product communities, online brand communities, virtual communities, virtual consumer communities, virtual P3 communities, and virtual consumption communities. However, all of these terms refer to what Hsu and others (2007) defined as "A cyber space supported by information technology ... centered upon the communications and interactions of participants to generate specific domain knowledge that enables the participants to perform common functions and to learn from, contribute to, and collectively build upon that knowledge" (p. 6) or what Porter and Donthu (2008) defined "An aggregation of individuals or business partners who interact based on a shared interest, where the interaction is at least partially supported and/or mediated by technology and guided by certain protocols and norms" (p. 115).

Along with many other researchers, Stephen (2015) drew the connection between the fact that marketing can be applied through social media and the fact that social media can alter the human behavior, or, in the marketing scheme, 'customer behavior'. Through applying the concepts of sentiment, motives, contents, attitudes and prospects, which can also be generated through social media marketing, it can be seen that the influence of social media can be more intentional for the organization than functional, because, through the feelings that social media can generate in the consumers, the organization can take full control of the messages that are being delivered to the audience about a certain product, brand or service (Agariya, Johari, Sharma, Chandraul, \& Singh, 2012; Keller, 2009).

According to the analysis of the study and the hypotheses testing, it can be seen that social media tools as an approach to marketing appeared to enjoy a better influence in intentional branding compared to the functional branding. The reason behind such results is attributed to the fact that intentional branding is concerned with how the customers see the brand. This, in turn, is controlled through the organization and how it presents its brand through the tools that social media presents for them, like the design, the shape and the delivery (Paquette, 2013).

\section{CONCLUSION}

The current research study aimed at locating social media marketing tools within the frame of functional and intentional branding; through the quantitative approach and the questionnaire as a tool, the research distributed the questionnaire to 150 individuals from which 133 were retrieved proper for statistical processing. The questionnaire was built by the researcher, and it has taken into perspective dimensions of both functional branding (usability-customer interaction) and intentional branding (ability-intention). The results of the study indicated that social media tools within the marketing frame appeared to be more of intentional branding tool than functional, as it presented for the marketers all the needed tools to control the messages that reach their customers about the brand of the product/service.

Based on the previous discussion and the results of the study gathered data, the researcher presented the following set of recommendations: 
- It is important for the organization to choose the suitable social media marketing tools for their brand; if these tools can perform magic for the brand, it is not necessary that it suits all brands and all services.

- Even though social media tools in marketing are mostly intentional, which revolves around controlling the image of the brand within the heads of the customers, customer interaction is really important as part of the marketing idea. It is nevertheless highly recommended to use and benefit from all the tools that are presented to the marketers from social media.

Being authentic and direct to the point is something which is really important in marketing, having the control over how customers see the brand is something worthy, but authenticity and genuine must be a big part of it. Based on that, organizations shouldn't manipulate the trust and truth.

\section{REFERENCES}

1. Agariya, A. K., Johari, A., Sharma, H. K., Chandraul, U. N., \& Singh, D. (2012). The role of packaging in brand communication. International Journal of Scientific \& Engineering Research, 3(2), 1-13.

2. Aho Williamson, D. (2011). Worldwide Social Network Ad Spending: 2011 Outlook. New York: eMarketer Inc.

3. Andrei, A. G., \& Zait, A. (2014). Worthy intentions on the road to brand trust. Management Dynamics in the Knowledge Economy, 2(3), 472.

4. Applegate, L., Austin, R., \& McFarlan, F. (2002). Creating Business Advantage in the Information Age. New York, NY: McGraw-Hill/ Irwin.

5. Ashley, C., \& Tuten, T. (2015). Creative strategies in social media marketing: An exploratory study of branded social content and consumer engagement. Psychology and Marketing, 32, 15-27.

6. Bernritter, S., Verlegh, P., \& Smit, E. (2016). Why Nonprofits Are Easier to Endorse on Social Media: The Roles of Warmth and Brand Symbolism. Journal of Interactive Marketing, 33, 27-42.

7. Bhat, S., \& Reddy, S. (1998). Symbolic and functional positioning of brands. Journal of Consumer Marketing, 15(1), 32-43.

8. Borrego, M., Douglas, E. P., \& Amelink, C. T. (2009). Quantitative, qualitative, and mixed research methods in engineering education. Journal of Engineering education, 98(1), 53-66.

9. Chang, T. (1996). Cultivating global experience curve advantage on technology and marketing capabilities. International Marketing Review, 13(6), 22-42.

10. Chi, H. (2011). Interactive Digital Advertising VS. Virtual Brand Community: Exploratory Study of User Motivation and Social Media Marketing Responses in Taiwan. Journal of Interactive Advertising, 12, 44-61.

11. Cox, S. A. (2010). Online Social Network Member Attitude Toward Online Advertising Formats (MA thesis, The Rochester Institute of Technology).

12. Dennis, C., Merrilees, B., Jayawardhena, C., \& Wright, L. T. (2009). E-consumer behavior. European Journal of Marketing, 43(9/10), 1121-1139.

13. Doorn, J., Lemon, K. E., Mittal, V., Na $\beta$, S., Pick, D., Pirner, P., \& Verhoef, P. C. (2010). Customer Engagement Behavior: Theoretical Foundations and Research Directions. Journal of Service Research, 13(3), 253-266.

14. eMarketer (2013). Advertisers boost social ad budgets in 2013. Retrieved from http://www.emarketer.com/Article/Advertisers-BoostSocial-Ad-Budgets-2013/1009688

15. Falls, J. (2010). What is engagement and how do we measure it? Social Media Explorer. Retrieved from http://www.socialmediaexplorer.com/2010/01/04/whatisengagement-and-how-to-wemeasure-it (accessed on January $4,2010)$.

16. Foroudi, P., Gupta, S., Nazarian, A., \& Duda, M. (2017). Digital technology and marketing management capability: achieving growth in SMEs. Qualitative Market Research: An International Journal, 20(2), 230-246.

17. Fournier, S., \& Alvarez, C. (2011) Brands as relationship partners: Warmth, competence, and inbetween.

18. Gensler, S., Völckner, F., LiuThompkins, Y., \& Wiertz, C. (2013). Managing brands in the social media environment. Journal of Interactive Marketing, 27, 242256. https://doi.org/10.1016/j. intmar.2013.09.004

19. Ghorbani, H., \& Fakhimi, A (2013). A Study of the Effect of Technology \& Marketing Strategies on Innovative Performance from the Standpoint of the Organizational Project Management (Case study: Home appliances manufacturing companies in Esfahan Province). International Journal of Academic Research in Business and Social Sciences, 3(11).

20. Hanna, R., Rohm, A., \& Crittenden, V. (2011). We're all connected: The power of the social media ecosystem. Business Horizons, 54(3), 265-273. 
21. Hashem, T. (2016). The impact of social media on customers' image for mobiles. Journal of Advances in Humanities and Social Sciences, 2(5), 269-277.

22. Hsu, M-H., Ju, T. L., Yen, C-H., \& Chang, C-M. (2007). Knowledge sharing behavior in virtual communities: The relationship between trust, self-efficacy, and outcome expectations. International Journal of Human-Computer Studies, 65(2), 153-169.

23. Hutton, G., \& Fosdick, M. (2011). The globalization of social media: Consumer relationships with brands evolve in digital space. Journal of Advertising Research, 51, 564-570.

24. Kaplan, A. M., \& Haenlein, M. (2010). Users of the world, unite! The challenges and opportunities of Social Media. Business horizons, 53(1), 59-68.

25. Keller, K. L. (2009). Building strong brands in a modern marketing communications environment. Journal of marketing communications, 15(2-3), 139-155.

26. Kervyn, N., Fiske, S. T., \& Malone, C. (2012). Brands as intentional agents framework: How perceived intentions and ability can map brand perception. Journal of consumer psychology: the official journal of the Society for Consumer Psychology, 22(2).

27. Kim, D., Spiller, L., \& Hettche, M. (2015). Analyzing media types and content orientations in Facebook for global brands. Journal of Research in Interactive Marketing, 9, 4-30. https://doi.org/10.1108/ JRIM-05-2014-0023

28. Laskey, H. A., Day, E., \& Crask, M. R. (1989). Typology of main message strategies for television commercials. Journal of Advertising, 18 , 36-41.

29. Lawford, C. (2009). Marketing in the Noughties: your brand is your product.

30. Lipsman, A., Mudd, G., Rich, M., \& Bruich, S. (2012). The Power of "Like". Journal of Advertising Research, 52, 40-52. http://dx.doi. org/10.2501/jar-52-1-040-052
31. Maarit Jalkala, A., \& Keränen, J. (2014). Brand positioning strategies for industrial firms providing customer solutions. Journal of Business \& Industrial Marketing, 29(3), 253-264.

32. Merchant, G. (2006). Identity, social networks and online communication. E-learning, 3, 235-244.

33. O'Reilly, T. (2005). What Is Web 2.0 Design Patterns and Business Models for the Next Generation of Software. Retrieved from: https:// www.oreilly.com/pub/a/web2/ archive/what-is-web-20.html (accessed on Aug 21, 2017).

34. Paquette, Holly (2013). Social Media as a Marketing Tool: A Literature Review (Major Papers by Master of Science Students. Paper 2). Retrieved from http:// digitalcommons.uri.edu/tmd_major_papers/2

35. Pereira, H. G., de Fátima Salgueiro, M., \& Mateus, I. (2014). Say yes to Facebook and get your customers involved! Relationships in a world of social networks. Business Horizons, 57, 695-702.

36. Pietro, D. L., \& Pantano, E. (2012). An Empirical Investigation of Social Network Influence on Consumer Purchasing Decision: The Case of Facebook. Journal of Direct Data and Digital Marketing Practice, 14, 18-29.

37. Porter, C. E., \& Donthu, N. (2008). Cultivating trust and harvesting value in virtual communities. Management Science, 54(1), 113-128.

38. Rick, F. (2008). Word of mouth and viral marketing: taking the temperature of the hottest trends in marketing. Journal of Consumer Marketing, 25, 178-182.

39. Schau, H. J., Muñiz Jr, A. M., \& Arnould, E. J. (2009). How brand community practices create value. Journal of marketing, 73(5), 30-51.

40. Schmitt, B. (2012). The consumer psychology of brands. Journal of Consumer Psychology, 22, 7-17.

41. Schneider, G. (2003). Electronic Commerce. Boston, MA: Thomson Course Technology, xxxv, 178.
42. Shankar, Venkatesh, Jeffery Inman, Murali Mantrala, Eileen Kelley, \& Ross Rizley (2011). Innovations in Shopper Marketing: Current Insights and Future Research Issues. Journal of Retailing, 1 , 29-42. https://doi.org/10.1016/j. jretai.2011.04.007

43. Shu-Chuan, C. (2011). Viral adver tising in social media: Participation in Facebook groups and responses among college-aged users. Journal of Interactive Advertising, 12, 30-43.

44. Singh, J. P. Kalafatis, S., \& Ledden, L. (2014). Consumer perceptions of cobrands: the role of brand positioning strategies. Marketing Intelligence \& Planning, 32(2), 145-159.

45. Sooknanan, P., \& Crichlow, K. (2014). The Role of Technology in the Marketing Communications Industry: An Exploratory Study of the Impact of North American Influence on Local Business in Trinidad and Tobago. Advances in Journalism and Communication, 2(3), 84-92. http://dx.doi. org/10.4236/ajc.2014.23009

46. Stelzner, M. (2013). The 2013 social media marketing industry report. Social Media Examiner. Retrieved from http://www.socialmediaexaminer.com/SocialMediaMar ketingIndustryReport2013.pdf

47. Stephen, A. (2015). The Role of Digital and Social Media Marketing in Consumer Behavior. Retrieved from http://eureka.sbs.ox.ac. uk/5851/1/Stephen_CurrentOpinionPsych_101215.pdf (accessed on Aug. 17, 2017).

48. Sukamolson, S. (2007). Fundamentals of quantitative research. Bangkok: EJTR.

49. Taecharungroj, V. (2016). Starbucks' marketing communications strategy on Twitter. Journal of Marketing Communications, 1-19.

50. Tafesse, W. (2015). Content strategies and audience response on Facebook brand pages. Marketing Intelligence \& Planning, 33, 927-943.

51. Töllinen, A., \& Karjaluoto, H. (2011). Is There a Need for New Marketing Communications Performance Metrics for Social Media? In 4th Annual EuroMed Confer- 
ence of the EuroMed Academy of Business, 19.-22.10.2011, Elounda, Crete, Greece (pp. 928-946). Crete, Greece: EuroMed Press.

52. Weinberg, D., \& Pehlivan, E. (2011). Social spending; Managing the social media mix. Business Horizons, 54, 275-282.
53. Zaglia, M. E. (2013). Brand communities embedded in social networks. Journal of Business Research, 66, 216-223.

54. Zalaghi, H., \& Khazaei, M. (2016). The Role of Deductive and Inductive Reasoning in Accounting Research and
Standard Setting. Asian Journal of Finance \& Accounting, 8(1), 23-37.

55. Zeng, F., Huang, L., \& Dou, W. (2009). Social Factors in User Perceptions and Responses to Advertising in Online Social Networking Communities. Journal of Interactive Advertising, 10, 1-13. 